\title{
PENDIDIKAN SEJARAH UNTUK GENERASI MILLENIAL DALAM TANTANGAN REVOLUSI INDUSTRI 4.0
}

\author{
Hari Naredi \\ Email : naredi19@yahoo.co.id \\ Prodi Pendidikan Sejarah FKIP UHAMKA
}

\begin{abstract}
Abstrak
Sejarah perkembangan peradaban manusia memberikan makna bagaimana budaya tumbuh dan berkembang dan berakhir kemudian tumbuh kembali, berkembang dan terus mengalami proses revisi, merevisi yang menuju kesempurnaan.Eksistensi Revolusi Industri adalah contoh kemajuan perkembangan ilmu pengetahuan dan teknologi,hari ini telah masuk pada Revolusi Industri 4.0 bersamaan dengan lahirnya satu generasi masyarakat baru yaitu, generasi Z, Generasi Millenial yang terpapar oleh budaya teknologi digital virtual. Pendidikan sejarah kini tengah dihadapkan dengan tantangan zaman, era disrupsion berhadapan dengan generasigenerasi millennial. Dari fenomena tersebut, bagaimana pendidikan sejarah menyikapi perubahan zaman tesebut? Bagaimana proses pembelajaran yang seharusnya dilakukan? Tujuan dari pendidikan sejarah adalah untuk membagun kesadaran sejarah. Sejarah di ajarkan bukan hanya generasi hari ini tetapi sejarah diajarkan untuk mempersiapkan generasi masa yang akan datang, yang mampu dan sanggup menghadapi tantangan yang makin kompleks, menyikapi dan mempertahankan negara bangsa ditengah tantangan globalisasi. Reorientasi filosofis dan kurikulum pendidikan sejarah hendaknya segera diwujudkan untuk pendidikan sejarah bagi generasi Millennial.
\end{abstract}

Kata Kunci: Pendidikan Sejarah, Generasi Millennial, Revolusi Industri 4.0

\section{Pendahuluan}

Sejarah di ajarkan untuk menumbuhkan generasi yang mampu berfikir kritis dan mampu melahirkan beragam ide baru mewujud dalam bentuk inovasi dalam berbagai bidang kehidupan. Sejarah mengajarkan pengalaman umat manusia dalam berinteraksi dengan sesamanya dan bahkan dengan alam dimana ia hidup dan berkehidupan.Sejarah yang didalamnya terdapat pengalaman yang positif dan konstruktif sekaligus pengalaman negatif dan destruktif, dialektika itu terus saling hadir dan menghadari dalam kisah-kisah perjalanan sejarahnya.

Jejak-jejak sejarah Revolusi Industri 4.0 ini bisa terjadi tentu melalui proses yang panjang dan beragam, dialektika pemikiran, ilmu dan teknologi yang saling berkaitan satu dengan yang lain. Diawali dari Revolusi Ilmu Pengetahuan dan mewujud menjadi Revolusi Industri 1.0.

Friedrich Engelsyang pertama kali yang memperkenalkan istilah Revolusi Industri

(Tristram, 2009: 281-282). Mesin uap menjadi titik awal menandai revolisi Industri 1.0 343 | Seminar Nasional Sejarah ke 4 Jurusan Pendidikan Sejarah Universitas Negeri Padang 
diperkirakan berlangsung antara tahun 1760-1830. Inggris adalah adalah negara pertama yang mampu menangkap pesan perubahan besar umat manusia di bidang ilmu pengetahuan dan teknologi. Inggris memiliki potensi besar dalam sektor industri manufaktur karena selain memiliki modal besar Inggris juga memiliki daerah jajahan yang luas yang kaya akan bahan mentah. Munculnya industry manufaktur dengan buruh urban dari desa-desa makin memperlancar proses produksi. Ada konsekuensi yang terjadi ketika proses produksi makin masif dengan upah buruh murah maka hanya pemilik modal besar saja yang dapat bertahan, kondisi ini memuncak karena terjadi kesejanganga sosial antara pemilik modal dan kaum buruh yang akan melahirkan revolusi sosial. Revolusi industri juga memunculkan paham sosialisme sekaligus dimulainya imperialism modern.

Revolusi Industri 2.0 ditandai dengan ditemukannya energi listrik. Konsep pembagian tenaga kerja dalam menghasilkan produksi dalam jumlah besar. Tahun 1870-1879 Thomas Alva Edison menciptakan Lampu dan telegraf pita kertas. Henry Ford mengubah pabriknya dengan menggunakan Ban Berjalan sehingga biaya produksi menjadi lebih murah dan dapat menurunkan harga produksi mobilnya. Akhirnya Ford berhasil menguasai pasar otomotif sehingga menjadi pabrik mobil terbesar saat itu.( https: // www. britannica. com/ technology/ history-oftechnology/ Perceptions-of-technology)

Teknologi makin progresif melahirkan Revolusi Industri 3.0. Jeremy Rifkin dalam bukunya yang berjudul The Third Industrial Revolution: How Lateral Power Is Transforming Energy, the Economy, and the World mengeksplorasi bagaimana teknologi Internet dan energi terbarukan bergabung untuk menciptakan Revolusi Industri 3.0. Jeremy Rifkin berharap untuk membayangkan ratusan juta orang memproduksi energi hijau mereka sendiri di rumah, kantor, dan pabrik mereka, dan berbagi satu sama lain dalam "internet energi," sama seperti kita sekarang membuat dan berbagi informasi online. Rifkin menjelaskan bagaimana Revolusi Industri Ketiga akan menciptakan ribuan bisnis, jutaan lapangan kerja, dan mengantarkan penataan ulang mendasar hubungan manusia, dari hierarki menjadi kekuatan lateral, yang akan berdampak pada cara kita melakukan perdagangan, mengatur masyarakat, mendidik anak-anak, dan terlibat dalam kehidupan sipil.(Jeremy Rifkin, 2011)

Revolusi Industri Ketiga digerakan oleh negara-negara kapitalis dan CEO global. Teknologi makin canggrih penggunaan elektronik dan teknologi informasi dalam rangka otomatisasi produksi. PLC (Programable Logic Controller). PLC atau sistem otomatisasi 
berbasis komputer berpengaruh kepada teknologi industri sehingga mesin industri tidak lagi dikendalikan oleh manusia. Dampak dari penerapan teknologi PLC menyebabkan biaya produksi menjadi murah. Contohnya bidang Industri musik melahirkan musik digital yang dengan cepat menguasai pasar.

Revolusi Industri Ketiga dapat pula dikatakan sebagai peralihan industri manufaktur beralih fungsi menjadi bisnis digital. Teknologi digital telah mengguncang industri media dan ritel. Para pekerja lebih menjadi tenaga progamer dan operator. Perusahaan-perusahan mobil dan barang konsumen lainnya telah mampu menghasilkan dua kali lebih. Pekerja manufaktur tidak lagi bekerja pabrik mereka, namun akan berpindah di kantor di dekat tempat tinggalnya, yang akan penuh dengan desainer, insinyur, spesialis IT, ahli logistik, staf pemasaran dan tenaga profesional lainnya. Industri manufaktur masa depan akan lebih membutuhkan keterampilan ketimbang jumlah tenaga kerja.

Revolusi Industri 4.0 hadir ketika banyak negara berkembang baru mulai beradaptasi terhadap Revolusi Industri generasi ketiga. Generasi Keempat perjalanan revolusi Industri di dinamakan Tren Otomatisasi dan pertukaran data terkini dalam teknologi (big data). Istilah Industri 4.0 adalah proyek dalam strategi teknologi canggih pemerintah Jerman yang mengutamakan komputerisasi pabrik.

Revolusi Industri 4.0. memaksa semua perusahaan untuk memeriksa kembali cara mereka melakukan bisnis dan mengambil bentuk yang berbeda. Beberapa perusahaan, menangkap batasbatas nilai baru, pengembangan bisnis baru di segmen yang berdekatan, sementara untuk yang lain, ini adalah tentang mengidentifikasi pergeseran nilai di sektor yang ada. Intinya tetap sama para pemimpin bisnis dan eksekutif senior perlu memahami bahwa gangguan (disrupsi) memengaruhi sisi permintaan dan penawaran bisnis mereka, pada gilirannya harus memaksa mereka untuk menantang asumsi tim operasi mereka dan menemukan cara baru dalam melakukan sesuatu. Singkatnya, mereka harus berinovasi terus menerus. (Klaus Schwab, 2017: 52-53).

Revolusi Industri ini tentu berdapak kepada masyarakat yang semakin hedonis. Industrialisasi modern cendrung membentuk masyarakat yang materialistik, karena cenderung juga kearah pembetukan karakter "mode of Having" dari pada "mode of Being" (Rochiati Wiriaatmadja, 2016:87). 
Perubahan di era disrupsi menurut Rhenald Kasali (2017), tidak hanya bermakna fenomena perubahan hari ini (today change) tetapi juga mencerminkan kakikat perubahan hari esok (the future change), hakikatnya tidak hanya berada pada perubahan cara atau strategi tetapi juga pada pada aspek fundamental dunia usaha. Revolusi Industri 4.0 memacu penelitian disamping untuk menyelesaikan persaoalan-persoalan ekonomi dan potensi nilai ekonomi tetapi juga diharapkan akan menyelesaikan berbagai persoalan masyarakat yang menyangkut masalah politik, ekonomi dan sosial. (https://id.wikipedia.org/wiki/Inovasi_disruptif).

Fenomena sejarah Revolusi Industri tersebut tentu tidak boleh diabaikan, bahkan harus menjadi perhatian dan fokus untuk dikaji dan dipelajari dalam Pendidikan Sejarah. Pendidikan sejarah akan menghadapi generasi millenial yang hidup dalam ruang dan waktu yang tanpa pagar lagi karena mereka dengan mudah dapat melakukan aktivitas sosial, ekonomi dan politik dengan memanfaatkan teknologi digital. Dunia sudah menjadi kampung global (global village). Dunia ada digenggaman tangan.

\section{Hasil dan Pembahasn}

Pandangan tentang terjadinya perubahan dalam berbagai bidang kehidupan akibat perkembangan ilmu pengetahuan dan teknologi mulai abad ke-18, sampai abad ke-21 dimaknai oleh Alvin Tovler sebagai Future Shock atau kejutan-kejutan masa depan, mengakibatkan kegoncangan seluruh institusi sosial. Alvin Tofler menegaskan bahwa "ilmu adalah perubahan" dan mengakselerasikan perolehan ilmu, dengan teknologi berarti mengakselesasi perubahan (Avlin Tovler, 1992: 37-38). Artinya dalam kehidupan umat manusia terdapat perubahan yang mendasar atau fundamental akibat perkembangan ilmu pengetahuan, teknologi dan komunikasi, sehingga terjadi beragam goncangan atau kejutan dari berbagai sendi kehidupan baik politik, sosial, ekonomi dan budaya umat manusia.

Perkembangan teknologi komunikasi yang masih juga menciptakan suatu perubahan dunia dimana kekhususan tempat dan individualitas di jembatani terus-menerus oleh jaringan teknologi komunikasi regional dan global, sehingga produk-produk budaya dapat dengan cepat melintas batas antar wilayah melampaui batas geografisnya (David Held,2004:151). Menegaskan kembali pendapat Alvin Tofler, Clayton Christensen profesor Harvard Business School dalam bukunya yang berjudul "The Inovator Dilema When New Technologies Cause Great to Fail" (1997), dengan istilah disrupsi (disruption) (Clayton Christensen, 1997: 20). Inilah salah satu 
kejutan itu lesatan ilmu dan teknologi komunikasi tidak mampu mempertahankan budaya lama, makna lokalitas seperti hilang, jejaring imajiner mampu melintas dinding batas suku, bangsa dan negara. Terjadilah sebuah kegagapan, kegalauan,kenyataan disrupsi ini jika tidak segera sadar maka mereka akan tertinggal. Disrupsi seperti tercabutnya sebuah pohon sampai keakarakarnya. Artinya terjadi perubahan yang radikal dan fundamental cara pandang dunia terhadap makna hidup dan kehidupan, akibat pengaruh kecanggihan ilmu dan tenologi komunikasi.

Sejarah panjang revolusi industri yang merupakan perwujudan dari revolusi ilmu pengetahuan telah di paparkan pada penjelasan sebelumnya, modernisasi ilmu pengetahuan dan teknologi adalah sejarah baru, spirit pencerahan telah mencapai puncak-puncak perkembangannya dan akan terus meluncur meninggalkan budaya-budaya klasik yang dianggap telah usang. Kesadaran generasi millennial tidak diragukan lagi jika terkait dengan teknologi informasi. Generasi Millenial adalah konsumen-konsumen fanatik, yang selau melalap dan melahap apa saja yang beredar dalam dunia maya.

Kehidupan masyarakat Indonesia saat ini memempati suatu masa dimana ilmu pengetahuan dan teknologi menjadi bagian dari dinamika kehidupan sehari-hari, menjadi bagian dari keluarga baru, mulai dari anak-anak, remaja, sampai orang dewasa. Teknologi yang makin canggih terutama teknologi informasi dan komunikasi menjadi bagian dari urat nadi baru pada lintas generasi. Kegagapan pada awalnya hanya bersifat sementara selanjutnya dengan mudahnya mereka berselancar masuk dalam gelompang dunia maya, mendekatkan yang jauh secara sprtiual dan menjauhkan yang dekat secara sosial.

Pendidikan sejarah hadir ditengah-tengah gelombang generasi millenial yang melihat kehadirannya seperti melihat hasil foto analog masa lalu, pada kertas film yang buram, samarsamar dan sama-sekali tidak menarik bagi mereka. Pendidikan sejarah dalam bentuk materi sejarah yang diajarkan sebagai pembelajaran sejarah di sekolah-sekolah dari tingkat dasar sampai tingkat menengah menjadi basi bagi mereka. Jangan salahkan mereka, karena mereka tidak pernah meminta untuk lahir di era millennial. Mereka adalah generasi yang terpapar oleh gelombang teknologi berbasis virtual. Pendidikan sejarah harus mampu melakukan reorientasi dan trasformasi, tranformasi filosofis dalam bidang kurikulum, materi, metode dan media pembelajaran sejarah serta bentuk evaluasi pembelajaran sejarah.

Reorientasi yang pertama adalah bagaimana sejarah mampu hadir dalam kerangka berfikir peserta didik secara lebih segar, artinya sejarah yang dipelajari memang benar-benar di 
butuhkan oleh mereka dan menjadi identitas dari dirinya. Identitias diri artinya mampu mewujud dalam kesadaran sejarah yang progresif. Progresifitas dalam pembelajaran sejarah artinya membangun kesadaran progresif sebagai sebuah identitas diri sebagai warga bangsa sekaligus warga dunia.

Bagaimana pendidikan sejarah secara filosofis memberi pesan akan eksistensi generasi millenial di era Revolusi Industri 4.0, bahwa kehadirannya harus bermakna dan bernilai bagi kemajuan dirinya bersamaan dengan tetap menyadari bahwa mereka sadar dimana ia hidup dan berkehidupan sebagai warga bangsa menjaga keutuhan dan keharmonisan dalam satu kesatuan negara Indonesia. Pendidikan sejarah harus dapat memberikan tahapan-tahapan pengenalan diri dan identitas kebangsaan mulai diawali dengan membangun paradigma kontekstual melalui lokalitas yang terdekat seperti, keluarga, ragam komunitas masyarakat sekitar, masyarakat sekolah yang akhirnya menyeluruh sebagai sebuah entitas kebangsaan (ke-Indonesiaan) bersamaan dengan proses pembelajaran tekstual sejarah dengan metode konstruktif dan melatih kemampuan berfikir kritis tentang sejarah bangsa Indonesia. Memberikan peluang berfikir kritis kemungkinan-kemungkina tentang bangsa Indonesia masa depan.

Pendekatan ilmu sejarah prosedur kronologis tidak bisa dihindarkan,dalam pendidikan sejarah, Proses pembelajaran sejarah tidah harus di mulai dari zaman pra sejarah, sungguh sangat jauh sekali penjelajahan ruang dan waktu jika pertama kali peserta didik bersentuhan dengan yang namanya sejarah, mereka harus belajar dari peristiwa sejarah yang tidak sama sekali mereka kenal. Manusia pra sejarah, jenis, bentuk dan fungsi alat-alat dari batu, kampak genggam, kapak lonjong, mata panah, nekara, moko, manusia hidup dalam gua-gua, sungguh sangat menjenuhkan apalagi guru hanya menggunakan metode ceramah.

Fenomena faktual yang dapat dijadikan contoh adalah Pemilu Presiden Repiblik Indonesia tahun 2019 ini, masih segar dalam ingatan sekitar tujuh bulan proses kampanye ditandai dengan polarisasi masyarakat Indonesia menjadi dua kubu yang seolah-oleh saling berhadap-hadapan, menandakan tidak dewasanya sebagian rakyat Indonesia untuk berfikir dan bersikapbijaksana. Sumber utama informasi tidak lagi melalui buku teks akademik atau artikelartikel ilmiah, tetapi rujukan masyarakat adalah media sosial.

Media sosial adalah ruang publik utama, ruang publik berbasis virtual telah memproduksi begitu banyak ragam informasi dan sungguh sangat mengkhawatirkan bahwa informasi tersebut banyak mengalami terdisistorsi informasi, media sosial tidak lagi mencerahkan pemikiran tetapi 
justru menjadi ajang konflik baru dalam berbagai ujaran yang tidak lagi memperdulian etika dan nilai-nilai budaya luhur bangsa. Mereka sebagain besar adalah generasi millenial yang tentu telah mengenal sejarah bangsaanya dari proses pembelajaran di sekolah-sekolah. Pendidikan sejarah yang diterima seolah tidak membekas dalam akal budinya, hilang begitu saja ketika dihadapkan kepada realitas polarisasi kehidupan politik bangsa.

Pendidikan sejarah harusnya mampu memberikan pencerahan, mencerdaskan, mendewasakan dalam berfikir, bersikap dan bertindak sebagai bagian dari warga bangsa, materimateri sejarah harus mengispirasi bagi peserta didik, memberikan ruang untuk berdialektika terhadap dunianya kemudian baru dibawa pada realitas historis yang syarat akan nilai-nilai luhur. Sejarah bangsa Indonesia adalah sejarah yang harus dipelajari melalui dialog kritis dan konstruktif memaknai arti kebangsaan, kemanusiaan, persaudaraan, dan persatuan. 'Creativity arises when one identifies an aspect of history or a subject previously uncovered, and sets out to portray it in one form or another. It also comes about during the portrayal process, as one considers the best mode of representation.' (Jackson, 2015).

Kurikulum pendidikan sejarah harus mampu melihat tantangan zaman dan psikologis generasi millennial. Seharusnya sejarah yang digunakan sebagai bagian dari pendidikan sejarah bersifat tematik dialektik. Pendidikan sejarah harus mampu keluar dari zona nyaman hanya dalam tataran naratif deskriptif saja. Zona itu adalah milik ilmu sejarah yang harus direproduksi ulang menjadi muatan-muatan pendidikan untuk menumbuhkan kerangka berfikir yang progresif dalam mewujudkan kesadaran sejarah.Kurikulum adalah bagian penting dari sistem pendidikan sejarah dan merupakan petujuk arah bagi langkah-langkah untuk mencapai tujuan-tujuan pendidikan sejarah yang relevan dengan perkembangan dan kemajuan bangsa Indonesia.

Perkembangan zaman yang begitu cepat dengan kemajuan ilmu pengetahuan dan teknologi informasi seharusnya diringi dengan perubahan cara pandang dalam pendidikan sejarah. Kurikulum pendidikan sajarah harus berevolusi memangkas bagian-bagian lama dan tidak relevan dari kurikulum selanjutnya mengintegrasikan dan menyeimbangkan dengan paradigma pengetahuan sosial yang baru.Kurikulum pendidikan sejarah harus menjadi kekuatan untuk menumbuhkan spirit progresifitas perkembangan generasi millenial tanpa melupakan nilainilai kebangsaan, kemanusiaan, pemahaman terhadap keberagamaan masyarakat, sehingga diharapkan tecipta masyarakat yang toleren dan saling menghargai perbedaan. 
Pendidikan sejarah harus meliputi tiga konsep waktu; masa lalu adalah refleksi, kontemplasi, hikmah dan nilai luhur yang tersimpan dari sejarah panjang umat manusia untuk dibawa ke masa kini. Masa kini adalah realitas yang harus dihadapi mewujud dalam bentuk sikap, dan tindakan nyata mencerminkan kesadaran sejarah (Doing History). Fenomena Revolusi Industri 4.0 adalah realitas yang tidak bisa dihindari bagaimana generasi millennial menyikapinya secara bijaksana dan dengan penuh kesadaran memanfaatkan kecanggihan teknologi untuk kepentingan diri dan bangsanya.Masa depan harus dihadapi dengan rasa percaya diri serta mampu mengantisipasi setiap perubahan yang terjadi.

Pemanfaatan informasi yang diperoleh dari pendidikan sejarah bagi kehidupan masa kini menjadi sangat penting untuk memaksimalkan potensi pendidikan sejarah sebagai pelajaran bagi generasi millenial, sebagaimana dinyatakan oleh Borries: morally judge historical events according to the standards of human and civil rights; explain the situation in the world today and find out the tendencies of change; acknowledge the traditions, characteristics, values, and tasks of our nation and society; internalize basic democratic value. (Stearns, Sexas dan Weinburg, 2000: 247)

Perspektif pendidikan sejarah dalam konteks kesadaran sejarah adalah upaya pembebasan akan sistem yang membelenggu kemanusiaan, keadilan serta membangun semangat persatuan dan kesatuan bangsa menuju kemajuan peradaban bangsa. Pendidikan sejarah tidak berhenti dimasa lampau tetapi membawa sejarah sebagai sebuah pendidikan yang mencerahkan bagi generasi millennial bangsa Indonesia yang tengah mengadapi tantangan budaya global yang makin massif masuk mempengaruhi pola berfikir, pola tindak dan pola bersikap yang terkadang tidak sesuai dengan nilai-nilai luhur bangsa.

\section{Simpulan}

Pendidikan sejarah sudah saatnya melakukan dekonstruksi ditengah pusaran revolusi Industri 4.0 dalam membangun kembali narasi sejarah bagi generasi millenial khususnya dalam pendidikan formal. Akhir dari pembelajaran sejarah seharusnya dapat memuwudkan kesadaran sejarah. Kesadaran bahwa kehadiran dirinya haruslah bermanfaat bagi hidup dan kehidupan umat manusia juga mampu memiliki kesadaran global tanpa menghilangkan kesadaran akan nilai-nilai luhur bangsa dan nasionalisme. Pendekatan doing history bagi generasi millenaial menuntut mereka berperan aktif, berfikir kritis dan inovatif serta bertindak dan berbuat dengan segenap 
kemampuannya untuk melihat persoalan-persoan bangsa serta kaitannya dengan pengaruh globalisasi terhadap eksistensi bangsa.

Pendidikan sejarah sekali lagi diharapkan memiliki peran untuk menumbuhkan pengetahuan, sikap dan tindakan yang memberikan inspirasi bagi generasi millennial. Kurikulum pendidikan sejarah mencerminkan progresivitas dan kebermaknaan teks dan kontektual sehingga dalam proses pembelajaran sejarah lebih menyenagkan didukung oleh materi, media, metode dan evalusi tepat sehinggaakan tumbuh karakter kebangsaan yang kuat dari generasi millenial serta mengasilkan kesadaran sejarah.

\section{DAFTAR PUSTAKA}

Christensen,Clayton. (1997) The Inovator Dilema When New Technologies Cause Great to Fail. Boston, MA: Harvard Business School Press.

Jackson, N. (2004) Creativity in History Teaching and Learning, in Subject Center for History, Claccics and Archeologi, Norman. jackson@heacademy.ac.uk.

Held David, (2004). Demokrasi dan Tantangan Global. Yogyakarta: Pustaka Pelajar

Kasali Rhenald. (2017), Disruption. Jakarta: Gramedia Pustaka Utama

Rifkin Jeremy. (2011) The Third Industrial Revolution: How Lateral Power Is Transforming Energy, the Economy, and the World. Palgrave MacMillan

Schwab, Klaus,(2017).The Fourth Industrial Revolution. New York: Crown Ublishing Group.

Tapscott, Don. (2008). Grown up Digital: How the Net Generation is Changing Your World. USA: McGraw Hill

Tovler, Avlin. (1992).Kejutan Masa Depan. Jakarta: Panji Simpati

Vaclav Smil, (2005). Creating the Twentieth Century: Technical Innovations of 1867-1914 and Their Lasting Impact. Oxford; New York: Oxford University Press. ISBN 0-19-5168747).

Wineburg, S. (2000). Making Histrotical Sense, dalam Knowing Teaching and Learning History: National and International Perspectives. New York: New York University Press

Wiriaatmadja, Rochiati (2016) Filosofi Pendidikan Sejarah, Bandung

Worf,Martin. (2007). Globalisasi Jalan Menuju Kesejahteraan. Jakarta: Yayasan Obor Indonesia https://www.britannica.com/technology/history-of-technology/Perceptions-of-technology) 